\title{
Adanya korelasi kadar TNF- $\alpha$ antara pemeriksaan hapusan lesi dengan pemeriksaan darah perifer pasien stomatitis aftosa rekuren Correlation of TNF-a between lesional swab and peripheral blood of mononuclear cell of recurrent aphthous stomatitis patient
}

\author{
Ali Yusran, Erni Marlina, Sumintarti \\ Bagian Oral Medicine, Fakultas Kedokteran Gigi \\ Universitas Hasanuddin \\ Makassar, Indonesia
}

\begin{abstract}
Recurrent aphthous stomatitis (RAS) is a common oral mucosal disease in human. This disease affect 20-25\% of population. The etiology remains unclear, but some of cytokine such as TNF-a is suspected to contribute in the pathogenesis of RAS. TNF-a is commonly measured by PBMC and lesional biopsy. These are invasive method and high skilled requirement. Another study used lesional swab to measure this cytokine without correlating the result with TNF-a measured by PBMC level. This study aimed to asses TNF- $\alpha$ level correlation between lesional swab and PBM of RAS patients. The study involved 10 subjects by inclusion criteria. Subjects have lesion swab and PBMC examined. Samples were analyzed by ELISA method. There is a correlation between lesional swab and PBMC of $T N F$ - a level RAS patients but this correlation did not statistically significant.
\end{abstract}

Key word: $T N F-\alpha$, Swab, PBMC, RAS

\begin{abstract}
ABSTRAK
Stomatitis aftosa rekuren (SAR) merupakan penyakit mukosa rongga mulut yang paling sering dijumpai pada manusia. Penyakit ini mengenai $20-25 \%$ populasi umum. Etiologinya belum jelas, namun diduga beberapa sitokin di antaranya TNF- $\alpha$, berperan dalam patogenesisnya. Sitokin TNF- $\alpha$ umumnya diteliti kadarnya pada serum dan biopsi lesi SAR. Sebuah penelitian lain menghitung kadar TNF- $\alpha$ melalui hapusan lesi SAR, dengan kekurangan belum dikorelasikannya hasil kadar TNF- $\alpha$ dari hapusan lesi SAR dengan kadar TNF- $\alpha$ pada serum yang relatif stabil. Penelitian ini bertujuan untuk mengetahui korelasi kadar TNF- $\alpha$ antara hapusan lesi dengan kadar TNF- $\alpha$ darah perifer pasien SAR. Penelitian ini melibatkan 10 subyek yang memenuhi kriteria inklusi. Diambil sampel hapusan lesi SAR sebagai kelompok hapusan, dan sampel darah dimasukkan ke dalam kelompok darah perifer. Kadar TNF- $\alpha$ dihitung dengan metode ELISA. Hasilnya menunjukkan adanya korelasi namun tidak signifikan $(\alpha>0,05)$. Disimpulkan bahwa ada korelasi antara kadar TNF- $\alpha$ hapusan ulser SAR dan kadar TNF- $\alpha$ PBMC pasien SAR menunjukkan kemungkinan digunakannya teknik hapusan lesi SAR untuk menghitung kadar TNF- $\alpha$.
\end{abstract}

Kata kunci: TNF- $\alpha$, hapusan, PBMC, SAR

Koresponden: Erni Marlina, Bagian Oral Medicine, Fakultas Kedokteran Gigi Universitas Hasanuddin, Jl. Kandea No. 5 Makassar, Indonesia. E-mail: e.marlina@yahoo.co.id.

\section{PENDAHULUAN}

Stomatitis aftosa rekuren (SAR) merupakan penyakit mukosa rongga mulut yang paling sering dijumpai pada manusia. Penyakit ini mengenai 20$25 \%$ populasi. Prevalensi tertinggi dijumpai pada pelajar Amerika Utara khususnya pada masa berlangsungnya ujian, dan pada kelompok sosioekonomi menengah ke atas. ${ }^{1,2}$

Banyak penelitian mengenai SAR difokuskan pada abnormalitas autoimun. Penelitian ini menelaah reaksi imun yang dimediasi oleh mediator berupa sitokin yang merupakan fokus utama dalam penelitian mengenai patogenesis autoimun.

Meskipun banyak sitokin yang diduga kuat berperan dalam etioimunologi SAR, namun TNF$\alpha$ dianggap berperan penting pada patogenesis penyakit SAR sehingga dijadikan sebagai target terapi SAR. Hal ini terbukti dengan penggunaan talidomid yang berfungsi mereduksi aktivitas TNF- $\alpha$ dengan mengakselerasi RNA-messenger, dan penggunaan pentoxifyline yang menghambat produksi TNF- $\alpha$. Kedua agen ini diketahui efektif dalam terapi SAR. ${ }^{3,4}$ Beberapa penelitian yang menunjukkan terjadinya peningkatan kadar TNF- $\alpha$ dilakukan oleh Buno dkk yang ditunjukkan dengan terjadinya peningkatan secara lokal pada ekspresi gen Th1 dan produksi sitokin sistemik IL2 , TNF- $\alpha$, dan IL-6 pada sel mononuklear darah perifer pada pasien SAR. Selain itu juga terjadi penurunan IL-10 mRNA pada pasien SAR yang diperkirakan sebagai akibat dari kegagalan sistem imun dalam menekan reaksi inflamasi mukosa rongga mulut. ${ }^{5}$ Penelitian lain dilakukan oleh Lin yang meneliti sitokin IL-2, IL-4, dan GM-CSF pasien SAR dengan menggunakan serum pasien 
dibanding dengan kontrol dan hasilnya adalah terjadinya peningkatan pada sitokin tersebut dibanding dengan kontrol. ${ }^{6}$ Demikian juga penelitian yang dilakukan oleh Yamamoto mengenai kadar serum sitokin IL-2, IL-4, IL-6, TNF- $\alpha$, serta GM-CSF yang semuanya meningkat. Penelitian tersebut menggunakan darah perifer pasien SAR sehingga diasumsikan tidak cukup mewakili produksi dan distribusi sitokin yang berperanan secara lokal oleh karena ada kemungkinan sitokin yang dijumpai diproduksi dan didistribusi dari infeksi atau dari stimulus lain, dan bukan spesifik akibat dari SAR. Pemeriksaan ini juga invasif meski merupakan unit analisis yang stabil. $^{7}$

Penelitian lain mengenai peningkatan TNF- $\alpha$, dilakukan oleh $\mathrm{Natah}^{8}$ dengan menggunakan biopsi lesi SAR. Hasilnya adalah terjadi peningkatan TNF- $\alpha$ dibanding kontrol. Sedang pada penelitian lain, Natah ${ }^{9}$ menghitung sitokin $\gamma / \delta$ TCR pada pasien SAR dengan melakukan biopsi eksisional pada ulser SAR yang dibandingkan dengan daerah normal disisi yang berlawanan dengan daerah ulser. Penelitianpenelitian ini meski cukup menggambarkan produksi dan distribusi sitokin lokal, namun juga invasif bagi pasien.

Gerber dkk yang meneliti gen polimorfisme IL-1 $\beta$, dengan menggunakan hapusan vestibulum vaginal atau dari mukosa bukal untuk meneliti peranan sitokin tersebut pada penyakit vulvar vestibulitis syndrome. ${ }^{10}$ Demikian pula yang dilakukan Guimaraes dengan meneliti gen polimorfisme IL-1 $\beta$, IL-6, IL-10, dan TNF- $\alpha$ dengan menggunakan hapusan lesi SAR. Gen polimorfisme adalah genotipe sel yang membawa pola warisan sebelumnya. Gen polimorfisme ini berkaitan dengan genetik khususnya DNA dan RNA suatu alel. Hasilnya adalah peningkatan signifikan IL-1 $\beta$ dan TNF- $\alpha$ heterozigot pada kelompok SAR. ${ }^{11}$

Marlina telah melakukan penghitungan kadar TNF- $\alpha$ dan IL-10 melalui pemeriksaan hapusan lesi dan hapusan mukosa normal pasien SAR dengan tujuan untuk memudahkan penghitungan kadar TNF- $\alpha$ dan IL-10 untuk dijadikan target diagnosis atau target terapi di masa yang akan datang. Hasilnya adalah teknik hapusan dapat digunakan untuk menghitung kadar sitokin tersebut. Akan tetapi penelitian ini belum didukung dengan kadar TNF- $\alpha$ dari pemeriksaan darah perifer pasien SAR, sedang serum merupakan spesimen yang relatif stabil dan telah banyak diteliti. ${ }^{12}$
Penelitian ini bertujuan untuk mengetahui apakah kadar TNF- $\alpha$ dari hapusan lesi SAR berkorelasi dengan kadar TNF- $\alpha$ dari darah perifer pasien SAR.

\section{METODE PENELITIAN}

Penelitian observasional analitik ini dilakukan di Klinik Penyakit Mulut Fakultas Kedokteran Gigi Universitas Hasanuddin (FKG Unhas), dilanjutkan dengan pemeriksaan darah lengkap di Balai Besar Kesehatan Makassar, dan penghitungan sitokin dilakukan di Tropical Disease Centre Universitas Airlangga Surabaya, dan dinyatakan laik etik oleh Komite Etik Penelitian FKG Universitas Airlangga melalui surat keterangan dengan nomor 11/KKEPK.FKG/II/2010. Populasi penelitian adalah pasien dengan SAR yang datang ke Klinik Penyakit Mulut FKG Unhas. Kriteria inklusi subyek penelitian adalah pasien laki-laki berusia 18-45 tahun, riwayat ulser kambuhan pada mukosa rongga mulut non-keratinisasi yang merupakan gambaran klinis SAR, tidak ada riwayat atau manfestasi penyakit sistemik atau bentuk imunodefisiensi lain yang diketahui dari hasil pemeriksaan darah lengkap, dan tidak ada riwayat penggunaan obat yang dapat mengganggu parameter penelitian. Pada kriteria inklusi ini juga dimasukkan kriteria lesi SAR, yaitu kekambuhan SAR paling kurang satu kali sebulan, lesi SAR hari ke-3 atau ke-4, diameter ulser $\geq 3 \mathrm{~mm}$, dan ulser terletak di daerah yang memiliki daerah berlawanan normal, simetris.

Total sampel diambil dari semua pasien yang menenuhi kriteria inklusi dan kriteria lesi SAR, dan bersedia ikut dalam penelitian. Jumlah sampel minimal ditentukan dengan rumus Lemekowich yaitu 7. Prosedur penelitian secara ringkas adalah diawali dengan seleksi pasien sesuai kriteria sampel. Selanjutnya, pasien yang memenuhi kriteria sampel diberikan penjelasan secara lisan dan tertulis mengenai tujuan dan metode cara kerja penelitian yang akan dilakukan. Pasien yang bersedia menjadi sampel diminta mengisi dan menandatangani informed consent secara sukarela. Setelah itu pengambilan hapusan lesi SAR dengan cara lesi dibersihkan dengan kapas steril, diisolasi dan diulasi cotton steril dengan cara memutar ujung cotton steril hingga semua bagian cotton steril mengenai lesi SAR. Dilakukan pemeriksaan darah lengkap sekaligus sentrifugasi PBMC, deteksi sitokin menurut petunjuk pabrik menggunakan ELISA Kit AssayPro Cat No. ET2010-1. 
Data dianalisis dengan uji One Sample Komlogorof Smirnov. Untuk mengetahui korelasi kadar sitokin antara hapusan lesi dan PBMC pasien SAR yang terdeteksi digunakan uji korelasi Pearson's dengan taraf kemaknaan $p<0,05$. Semua uji dihitung dengan menggunakan SPSS 16,0 for windows.

\section{HASIL}

Tabel 1. Kadar TNF- $\alpha$ pada hapusan lesi SAR dan pada PBMC pasien SAR

\begin{tabular}{ccc}
\hline Subyek & $\begin{array}{c}\text { TNF- } \alpha \text { hapusan } \\
\text { ulser SAR }(\mathrm{pg} / \mathrm{ml})\end{array}$ & $\begin{array}{c}\text { TNF- } \alpha \text { PBMC pasien } \\
\text { SAR }(\mathrm{pg} / \mathrm{ml})\end{array}$ \\
\hline 1 & 18,12 & 59,00 \\
2 & 10,01 & 54,00 \\
3 & 13,61 & 52,12 \\
4 & 3,95 & 69,00 \\
5 & 44,33 & 18,00 \\
6 & 9,09 & 12,00 \\
7 & 36,79 & 15,70 \\
8 & 3,09 & 41,20 \\
9 & 7,30 & 18,00 \\
10 & 14,77 & 26,20 \\
\hline Mean & $16,10($ SD 13,81$)$ & $36,52($ SD 20,97) \\
\hline
\end{tabular}

Catatan: pemeriksaan dilakukan di ITD Universitas Airlangga, 24 November 2010 dengan menggunakan TNF- $\alpha$ ELISA Kit, AssayPro Cat No. ET2010-1).

Pada tabel 1 tampak nilai kadar TNF- $\alpha$ masing-masing subjek untuk hapusan lesi SAR dan pada PBMC pasien SAR. Nilai-nilai tersebut masing dalam rentang standar.

Sebelum dilakukan uji dan analisis korelasi, dilakukan uji normalitas pada masing-masing kelompok dengan menggunakan uji Kolmogorov Smirnov. Hasilnya seluruh kelompok penelitian mempunyai nilai $\mathrm{p}>0,05(p=0,601$ untuk TNF- $\alpha$ hapusan ulser SAR dan $p=0,763$ untuk TNF- $\alpha$ PBMC pasien SAR), yang berarti data pada seluruh kelompok penelitian berdistribusi normal.

Pada tabel 2, setelah dilakukan uji Korelasi Pearson untuk melihat korelasi antara kadar TNF-

Tabel 2. Korelasi linear Pearson antara TNF- $\alpha$ hapusan ulser, dan TNF- $\alpha$ PBMC pasien SAR

\begin{tabular}{llrr}
\hline & & $\begin{array}{c}\text { TNF- } \alpha \\
\text { hapusan }\end{array}$ & $\begin{array}{c}\text { TNF- } \alpha \\
\text { serum }\end{array}$ \\
\hline $\begin{array}{l}\text { TNF- } \alpha \\
\text { hapusan }\end{array}$ & Korelasi Pearson & $1^{* *}$ & $-.445^{*}$ \\
& Sig. (2-tailed) & & .197 \\
& $\mathrm{~N}$ & 10 & 10 \\
TNF- $\alpha$ & Korelasi Pearson & $-.445^{*}$ & $1^{* *}$ \\
serum & Sig. (2-tailed) & .197 & \\
& $\mathrm{~N}$ & 10 & 10 \\
\hline * Korelasi signifikan pada level 0,05 (2-tailed) & \\
$* *$ Korelasi signifikan pada level 0,01 (2-tailed) &
\end{tabular}

$\alpha$ hapusan lesi ulser dengan PBMC pasien SAR didapatkan korelasi yang tidak signifikan ( $\mathrm{p}>$ $0,05)$ dengan nilai $-0,445$.

\section{PEMBAHASAN}

Sitokin yang diduga berperan pada etiologi SAR merupakan biomarker imunologis yang penting dan dapat dilihat pada seluruh cairan yang berasal dari limfonodus. Sitokin, khususnya TNF$\alpha$ dihasilkan oleh berbagai jenis sel, diantaranya TNF- $\alpha$ yang dihasilkan oleh limfosit dan makrofag. Sel-sel penghasil sitokin tersebut dapat dijumpai pada lesi SAR, yaitu daerah ulserasi merupakan nekrosis jaringan superfisial dengan eksudat fibrinopurulen yang terdiri dari gumpalan fibrin, sejumlah sel darah merah yang membentuk hemorrhagic foci, netrofil dan debris seluler yang menutupi daerah nekrotik. Epitel diinfiltrasi dengan sejumlah limfosit intraepitel dan beberapa netrofil. Netrofil mendominasi daerah ulserasi meskipun daerah di sekitarnya tetap bersifat mononuklear. ${ }^{13-16}$

Umumnya sitokin diproduksi dengan cara yang sementara karena fungsinya untuk amplitudo dan durasi respon inflamasi-imun sehingga regulasinya sangat berkaitan dengan adanya benda asing atau antigen lain. Tidak seperti hormon, kebanyakan sitokin beraksi secara lokal dengan cara parakrin ataupun otokrin. Karena itu sitokin yang berasal dari limfosit umumnya tidak dijumpai dalam sirkulasi, namun sel-sel nonlimfoid dapat terpicu oleh produk bakteri atau antigen lain sehingga akan melepaskan sitokin yang dapat terdeteksi dalam darah. Sitokin yang distimulasi oleh kondisi lokal ini khususnya pada pasien SAR dapat terdeteksi dalam darah, kemungkinan karena TNF- $\alpha$ yang dilepaskan akibat simulasi dari cytotoxic $T$ - lymphocyte (CTL) akan meningkatkan eskpresi sel endotel sehingga sitokin kemotaksis (chemokine) menyebabkan migrasi sel-sel inflamasi ke lokasi inflamasi dan sebaliknya menyebabkan sitokin yang mengkode sel-sel inflamasi masuk ke dalam darah. ${ }^{17,18}$ Beberapa sitokin lain, misalnya IL-1 dan TNF- $\alpha$ juga dijumpai dalam bentuk membran yang dapat mengeluarkan efek stimulasinya tanpa menjadi soluble. ${ }^{18}$

Pengukuran sitokin umumnya menggunakan teknik vena puncture untuk pengambilan spesimen darah, atau teknik biopsi baik berupa fine needle aspiration biopsi (FNAB) maupun dengan biopsi eksisional untuk selanjutnya diuji dengan berbagai macam metode. ${ }^{9,19}$ Perkembangan pengetahuan dan teknologi semakin mendukung peningkatan 
uji sitokin baik untuk keperluan penelitian maupun untuk aplikasi klinis. ${ }^{20,21}$ Salah satunya adalah dengan pemeriksaan sitokin yang menggunakan teknik hapusan. ${ }^{20}$ Teknik hapusan adalah sebuah teknik yang menggunakan cotton strip sterile atau menggunakan brush yang awalnya banyak digunakan untuk pemeriksaan mikroorganisme terutama pada jaringan mukosa. Teknik ini dilakukan dengan cara membuat hapusan pada permukaan mukosa, 3-5 kali untuk mengambil mikroorganisme atau eksfoliasi sel pada daerah tersebut. ${ }^{22}$ Marlina $^{12}$ melakukan penelitian hitung kadar sitokin TNF- $\alpha$ dan IL-10 pada hapusan ulser SAR, hasilnya adalah terjadi peningkatan TNF- $\alpha$ dan penurunan IL-10 pada hapusan tersebut.

Teknik hapusan ini banyak digunakan untuk mengamati polimorfisme gen sitokin pada jaringan mukosa, baik mukosa vagina, mukosa usus maupun pada mukosa rongga mulut. ${ }^{10,11}$ Teknik ini juga digunakan untuk analisis imunoblot dan optica densitometry untuk mengetahui perubahan ekspresi biomarker cyclin D1 dan sebagai teknik pengganti pemeriksaan darah bagi yang kontraindikasi dan menolak pemeriksaan sitokin gen polimorfisme untuk penyakit Hodgkin Limfoma. ${ }^{23}$ Selain itu, teknik ini digunakan untuk mengumpulkan sel-sel servikal dan mukus servikovaginal, ${ }^{20}$ untuk pemeriksaan sitokin uretra, ${ }^{24}$ cairan vagina ${ }^{25}$ dan teknik ini telah diuji dengan membandingkan konsentrasi sitokin IL-6 antara aplikator hapusan yang dilakukan oleh ahlinya dan yang dilakukan sendiri oleh subjek dengan hasil korelasi linear dengan simpulan bahwa hapusan baik yang dilakukan oleh ahlinya maupun yang dilakukan sendiri oleh subyek dapat diterima. ${ }^{26,27}$

Hasil penelitian ini menunjukkan bahwa terdapat korelasi TNF- $\alpha$ antara hapusan ulser SAR dengan PBMC pasien SAR, meski korelasi ini tidak signifikan. Semua uji TNF- $\alpha$ berdistribusi normal. Nilai koefisien korelasi bernilai antara -1 sampai 1 . Semakin mendekati nilai -1 atau nilai 1 maka korelasi akan semakin kuat dan semakin mendekati nilai 0 korelasi akan semakin lemah.

Korelasi ini dijelaskan dengan kemungkinan adanya hipersensitivitas imun yang menyebabkan reaksi berlebihan terhadap organisme mukosa rongga mulut dan atau oleh self-antigen yang belum diketahui sumbernya sehingga menyebabkan munculnya manifestasi klinis SAR. Tidak signifikannya nilai korelasi ini kemungkinan disebabkan oleh banyak faktor, diantaranya selain jumlah sampel yang kecil, juga disebabkan karena proses stabilisasi lokal cenderung lebih cepat terjadi dibanding proses stabilisasi sistemik. Selain itu, penelitian lain menunjukkan adanya kecenderungan peningkatan TNF- $\alpha$ pada subyek SAR meskipun subyek tersebut tidak sedang mengalami fase akut SAR.

\section{SIMPULAN}

Adanya korelasi antara kadar TNF- $\alpha$ hapusan ulser SAR dan kadar TNF- $\alpha$ PBMC pasien SAR menunjukkan kemungkinan digunakannya teknik hapusan lesi SAR untuk menghitung kadar sitokin khususnya TNF- $\alpha$ khususnya pada penelitian lain.

\section{SARAN}

Perlu dilakukan penelitian dengan sampel yang lebih besar, dengan mencakup daerah geografis yang luas.

\section{UCAPAN TERIMA KASIH}

Ucapan terima kasih kami sampaikan kepada Rektor Unhas, dan Dekan FKG Unhas beserta staf yang telah menyelenggarakan program hibah ini, para reviewer yang memberi saran dan masukan, serta kepada staf bagian Oral Medicine yang ikut mendukung keberhasilan penelitian ini.

\section{DAFTAR PUSTAKA}

1. Field A, Longman L. Tyldesley's oral medicine. $5^{\text {th }}$ Ed. Oxford: Oxford University Press; 2003.p.3-9.

2. Greenberg SM. Ulserative, vesicular and bullous lesions. In: Greenberg MS, Glick M, editors. Burket's oral medicine diagnosis and treatment. $10^{\text {th }}$ Ed. Hamilton: BC Decker, Inc; 2003. p.50-102.

3. Natah SS, Konttinen YT, Enattah NS, Ashammaktil N, Sharkey KA, Hayrinen-Immonen R. Recurrent aphthous ulcers today : a review of the growing knowledge. Int J Oral Maxillofac Surg 2004; 33: 221-34.

4. Scully C. The diagnosis and management of reccurent aphthous stomatitis. J Am Dent Assoc 2003; 134: 200-7.

5. Buno IJ, Huff JC, Weston WL, Cook DT, Brice SL. Elevated levels of interferon gamma, tumor necrosis alpha, interleukin 2, 4 and 5, but not interleukin 10, are present in recurrent aphthous stomatitis. Arch Dermatol 1998; 134: 827-31.

6. Lin SS, Chou YM, Ho CC. Study of the viral infection and cytokines associated with recurrent aphthous ulceration. Microbes and Infection 2005; 7: 635-44.

7. Yamamoto T, Yoneda K, Ueta E, Osaki T. Serum cytokines, interleukin-2 receptors, and soluble intercellular adhesion molecule-1 in oral disorders, Oral Surg Oral Med Oral Pathol Oral Radiol Endodon 1994; 78: 737-5. 
8. Natah SS. Recurrent aphthous ulceration: imunopathological aspects. [thesis]. Helsinki: University of Helsinki; 2001.p.30-60.

9. Natah SS, Immonen HR, Hietanen J, Patinen P, Malmstrom M, Savilahti E, et al. Increased density of lymphocytes bearing $\gamma / \delta \mathrm{T}$-ce;p; receptors in recurrent aphthous ulceration (RAU). Int $\mathrm{J}$ Oral Maxillofac Surg 2000; 29: 375-80.

10. Gerber S, Bongiovanni AM, Ledger WJ, Witkin SS. Interleukin-1 $\beta$ gene polymorphism in women with vulvar vestibulitis syndrome. Eur J Obst Gyn Repro Biol 2003; 107: 74-7.

11. Guimaraes ALS, Correia-Silva JF, de Santos RA, Victoria JMN, Diniz MG, Costa FD, Gomes RS. Investigation of functional gene polymorphisms IL$1 \beta$, IL-6, IL-10, and TNF- $\alpha$ in individual with recurrent aphthous stomatitis. Arch Oral Biol 2007; 52: 268-72.

12. Marlina E. Teknik hapusan mukosa mulut ada ulser RAS minor melalui perbedaan kadar TNF- $\alpha$ dan IL10. [thesis]. Surabaya: Univ. Airlangga; 2010.

13. Lehner T. Pathology of recurrent oral ulceration and oral ulceration in Behçet's syndrome: light, electron and fluorescence microscopy. J Pathol 2010; 97: 481-93.

14. Mills MP, Mackler BF, Nelms DC, Peavy DL. Quantitative distribution of inflammatory cells in recurrent aphthous stomatitis. J Dent Res 2010; 59: 562-6.

15. Schroeder HE, Müller-Glauser W, Sallay K. Stereologic analysis of leukocyte infiltration in oral ulcers of developing Mikulicz aphthae. Oral Surg Oral Med Oral Pathol 2010; 56: 629-40.

16. Hayrinen-Immonen R. Immune-activation in recurrent oral ulcer ROU. Scand J Dent Res 2010; 100: 222-7.

17. Pinchuk G. Theory and problems of immunology. New York: McGraw-Hill; 2002. p.158-81.
18. Roitt IM, Delves PJ. Roitt's essential immunology. $10^{\text {th }}$ Ed. Massachusetts: Blackwell Pub.; 2008. p.177-89.

19. Lewkowicz N, Lewkowicz P, Banasik M, Kurnatowska A, Tchorzewski. Predominance of Type 1 cytokines and decreased number of CD4+CD25+high $\mathrm{T}$ regulatory cells in peripheral blood of patients with recurrent aphthous ulcerations. Immunol Letters 2005; 99: 57-62.

20. Hill JA. Cytokines in human reproduction. Toronto: Wiley-Liss; 2000. p.80-1.

21. O'Gorman RGM, Donnenberg DA., eds. Handbook of human immunology. $2^{\text {nd }}$ Ed. London: CRC Press; 2008. p.495-525.

22. Spafford MF, Koch WM, Reed AL, Califano JA, $\mathrm{Xu}$ LH, Eisenberger CF, Yip L, et al. Detection of head and neck squamous cell carcinoma among exfoliated oral mucosal cells by microsatellite analysis.Pubmed 2008 [cited 2008 Nov 15] available from URL:www.ncbi.hlm.nih.gov/ pubmed.

23. Dragnev KH, Petty JW, Shah S, Biddle a, Desai NB, Memoli V. Bexarotene and erlotinib for arodigestive tract cancer. J Clin Oncol 2005; 23: 8757-64.

24. Pate SM, Hedge SP, Sibley DA, Russel MW, Hook III EW, Mestecky J. urethral cytokine and immune responses in Chlamydia trachomatis-infected males. Infection and Immunity 2001; 11: 7178-81.

25. Agnew KJ, Aura J, Nunez N, Lee Z, Lawler R, Richardson CE, et al. Effect of semen on vaginal fluid cytokines and secretory leukocyte protease inhibitor. Inf Dis Obs Gyn 2008; 1-4.

26. Faro CJ, Holler LM, Bishop K. Comparison of vaginal cytokine collection methods. Am J Reprod Immunol 2006; 55(5): 315-20.

27. Savage WN, Boras VV. Recurrent aphthous ulcerative disease: presentation and management. Aus Dent J 2007; 52(1): 10-5 